\title{
PENDIDIKAN PESANTREN DAN PERUBAHAN NILAI RELIGIUS
}

\author{
Ali Wafa \& Moh. Wardi \\ STAI Nazhatut Thullab Sampang \\ E-mail: awafa9851@gmail.com
}

\begin{abstract}
Abstrak:
Penelitian ini merupakan kajian teorits tentang pendidikan pesantren sebagai lembaga pendidikan Islam tertua di Indonesia yang sudah memberikan banyak kontribusi dalam perubahan sosial kehidupan bangsa melalui penanaman nilainilai religius, yang dalam hal ini relevan dengan tujuan pendidikan Nasional, yakni berbudi luhur, amal shalih, kegiatan keagamaan sehari-hari, kemandirian, kesehatan rohani dan tanggung jawab kemasyrakatan. Hal tersebut menjadikan pendidikan pesantren mampu mengendalikan perubahan nilai-nilai dalam kehidupan. Beberapa pendapat mengatakan bahwa terdapat lima komponen pesantren untuk dapat disebut sebagai pesantren, antara lain: ada kiai, pondok, masjid, santri serta pengkajian kitab klasik (gundul). Kelima komponen tersebut merupakan satu-kesatuan yang saling berkaitan dalam pendidikan pesantren. Dalam penelitian ini fokus pada proses pendidikan pesantren dalam merubah dan menanmkan nilai-nilai kepada para santri.
\end{abstract}

Kata Kunci: Pendidikan Pesantren, Perubahan Nilai Religius

\begin{abstract}
:
This research is a theoretical study of Islamic boarding school education as the oldest Islamic educational institution in Indonesia that has contributed a lot in the social change of the nation's life through the cultivation of religious values, as contained in the national educational goals of nobility, good deeds, daily religious, independence, spiritual health and community responsibility. This makes the boarding school education able to control changes in values in life. Some opinions say that there are five components of the boarding school to be called as boarding school, among others: there are teacher of Islam, cottage, mosques, strict adherent of Islam and yellow book teaching (classical). The five components are a unit that cannot be separated from boarding school education. In this case the writer will explain how the boarding school education process in changing and instill values to the strict adherent of Islam.
\end{abstract}

Keywords: Islamic Boarding School Education, Change in Religious Value 


\section{Pendahuluan}

Sejauh ini, salah satu lembaga pendidikan agama Islam di Indonesia yang masih eksis adalah pesantren. Hal ini disebabkan oleh dua alasan. Pertama, dunia pesantren yang mewarisi dan memelihara kontinuitas tradisi Islam yang dikembangkan ulama dari masa ke masa, tidak terbatas pada periode tertentu dalam sejarah. Menurut Martin Van Bruinessen, munculnya pesantren ini adalah untuk mentransmisikan Islam tradisional sebagaimana yang terdapat dalam kitabkitab klasik yang ditulis berabad-abad yang lalu. Kedua, pesantren merupakan tempat untuk mendidik calon-calon pemimpin di tengah masyarakat yang karenanya kebutuhan akan pesantren merupakan kebutuhan yang tidak dapat diabaikan begitu saja. Hal ini dapat dilihat dari realitas sosial bahwa banyak di antara tokoh masyarakat merupakan jebolan pesantren. ${ }^{1}$

Pendidikan pesantren merupakan lembaga pendidikan Islam yang dari segi kuantitas sangat bersar dan bahkan menyebar luas diberbagai plosok tanah air yang sudah tidak diragukan lagi dalam kontribusinya pada pengembangan masyarakat Indonesia yang shalih, spiritualis dan beradab. Bahkan, lembaga tersebut telah banyak melahirkan pemimpin negeri ini. Hal tersebut terlihat para lulusan pendidikan pesantren telah banyak yang berpartisipasi aktif dalam pembangunan bangsa. ${ }^{2}$ Kontribusi pesantren pada periode awal tampak dalam keikutsertaan mereka demi kemerdekaan negera Indonesia (wilayah Nusantara) hingga berhasil mengusir para penjajah dari tanah air ini. Muhammad Mansur Suryanegara, seorang pakar sejarah di UNPAD Bandung berpendapat, betapa sulit menemukan gerakan melawan penjajah di Indonesia ini kalau tidak dipelopori oleh masyarakat pesantren. Sedangkan peran pesantren di masa sekarang juga sangat jelas. Contoh yang paling nyata adalah sulitnya pemerintah memasyrakatkan program bila tidak melalui pesantren. Adapun peran pesantern di masa mendatang agaknya akan tetap besar. Gejala yang ada sekarang dapat dijadikan indikator untuk meramal demikian. ${ }^{3}$

Dalam sejarahnya, pesantren mempunyai posisi yang urgen dalam membangun dan perkembangan peradaban Indonesia, khususnya Jawa. Pesantren pernah berperan sebagai cultural broker, yaitu penyeleksi budaya yang akan dikonsumsi oleh masyarakat bagi arus modernitas pedesaan. Peran lainnya adalah peramu budaya Islam dan budaya lokal yang menjadi simpul perjumpaan Islam dan budaya lokal dengan melakukan pribumisasi Islam. Kedua peran tersebut menegaskan keberpihakan pendidikan pesantren terhadap lokalitas (masyarakat dan budaya). Ia tidak hanya mengintegerasikan budaya namun juga ragam etnis dan status sosial. Peran sebagai lembaga keagamaan sekaligus lembaga sosial, pendidikan pesantren mengajarkan, mengembangkan, dan menyebarkan ilmu agama Islam sekaligus nilai-nilai kehidupan yang seimbang.4

Selain keberhasilan di atas, pesantren juga membentuk jaringan yang mempunyai kekuatan politik. Banyaknya tokoh-tokoh politik yang berasal dari

\footnotetext{
1 Ahmad Kamaruzzaman Bustamam, Islam Historis: Dinamika Studi Islam di Indonesia, cet. II, (Yogyakarta: Jogja Bangkit Publisher, 2017), 122.

${ }^{2}$ Ahmad Tafsir, Ilmu Pendidikan Islami, (Bandung: PT. Remaja Rosdakarya, 2013), 289-290.

${ }^{3}$ Ibid. 290.

${ }^{4}$ Choirul Fuad Yusuf dkk, Pesantren dan Demokrasi: Jejak Demokrasi dalam Islam, (Jakarta: CV. Titian Pena Abadi, 2011), 96.
} 
pesantren mengindikasikan bahwa lembaga tersebut mendidik santrinya untuk siap terjun ke tengah-tengah masyarakat luas dalam berbagai bidang. Di samping itu, pesantren menghasilkan produsen pemikiran Islam di Indonesia. ${ }^{5}$ Dari situlah dapat dipahami bahwa posisi pesantren (dayah atau surau) sejak awal Islam masuk ke Indonesia telah memainkan peran yang penting dalam proses mencerdaskan kehidupan bangsa. ${ }^{6}$

Bahkan pesantren telah diyakini berhasil mencetak genirasi yang tidak diragukan lagi dalam berbagai bidang baik ditingkat nasional maupun internasional. Selanjutnya, pesantren juga berfungsi sebagai basis dakwah sekaligus media kontrol terhadap perilaku budaya dan pengawal umat menuju maslahat. Sebagai pengawal umat, dalam hal ini kiai dan santri terkadang harus bekerja keras siang malam demi mewujudkan kemaslahatan tersebut di tengah kehidupan umat. Bahkan, sesekali mereka harus melawan masyarakat yang enggan menerima nilai-nilai baru yang mereka bawa. ${ }^{7}$

Dalam hal ini proses pemberdayaan masyarakat yang dilakukan oleh pesantren pada hakikatnya adalah sebuah bentuk penjabaran nilai-nilai hidup keagamaan bagi kemaslahatan masyarakat luas. Dengan cara ini, pesantren bisa menjadi aset masyarakat yang didukung dan dipelihara oleh kalangan yang lebih luas serta memiliki kesempatan untuk mewujudkan praktik ibadah sosial dengan memindahkan arena peribadatan dari masjid ke tengah-tengah masyarakat. Selain itu, praktik pemberdayaan tersebut juga dapat mendekatkan pesantren dengan masyarakat sehingga proses penanaman nilai keagamaan dapat dilaksanakan secara mudah. ${ }^{8}$

Dari deskripsi di atas, sangat menarik untuk dikaji lebih lanjut tentang pendidikan pesantren sebagai sebuah lembaga pendidikan Islam tertua di Indonesia. Dalam kajian ini akan dipaparkan tentang potret pendidikan pesantren, unsur-unsur dalam pesantren, tipologi pendidikan pesantren, kurikulum pendidikan pesantren, tujuan pendidikan pesantren dan nilai-nilai religius dalam pendidikan pesantren.

\section{Potret Pendidikan Pesantren}

Kata pondok berasal diambil dari bahasa Arab Funduq yang berarti ruang tidur dan asrama-asrama para santri yang terbuat dari bambu. Hal ini yang menjadi ciri khas tradisi pesantrern yang membedakan dengan sistem pendidikan Islam tradisional lainnya, seperti masjid, surau atau langgar. ${ }^{9}$ Sedangkan istilah, pesantren berasal dari kata "santri" yang mendapat imbuhan "pe" di depan dan "an" diakhir yang dalam bahasa Indonesia berarti tempat tinggal santri, tempat para pelajar mengikuti pelajaran agama. Sedangkan istilah "santri" berasal dari kata shastri (castri = India), dalam bahasa Sansekerta berarti orang yang mengetahui kitab Suci Hindu. Selain itu, kata shastri berasal dari kata shastra yang

\footnotetext{
5 Ahmad Kamaruzzaman Bustamam, Islam Historis: Dinamika Studi Islam di Indonesia, cet. II, (Yogyakarta: Jogja Bangkit Publisher, 2017), 127.

6 Muhammad Khalil, Sejarah Kebudayaan Islam, (Jakarta: Kementerian Agama Republik Indonesia, 2016), 36.

${ }^{7}$ Choirul Fuad Yusuf dkk, Pesantren dan Demokrasi: Jejak Demokrasi dalam Islam, 28.

8 Ibid. 120.

9 Abdullah Aly, Pendidikan Islam Multikultural di Pesantren: Telaah Terhadap Kurikulum Pondok Pesantren Modern Islam Assalaam Surakarta, (Yogyakarta: Pustaka Pelajar, 2011), 159-160.
} 
berarti buku-buku suci, buku-buku agama atau buku tentang ilmu pengetahuan. Namun setelah kedatangan Islam ke indonesia, tujuan lembaga ini diubah dari tujuan semula, yaitu tempat belajar agama Hindu menjadi tempat mempelajari ajaran Islam. ${ }^{10}$

Secara terminologis pesentren adalah model desa kecil yang di dalamnya terdapat seperangkat aturan yang harus dipatuhi oleh segenap penghuninya. Aturan tersebut telah mengakar, terkadang tidak tertulis, namaun menjadi hukum hidup (living law), yang tidak boleh dilanggar sam sekali. ${ }^{11}$ Pesantren merupakan lembaga pendidikan tradisional Islam untuk mempelajari, memahami, mendalami, menghayati, dan mengamalkan ajaran Islam dengan menekankan pentingnya moral keagamaan sebagai pedoman perlaku sehari-hari. ${ }^{12}$ Walaupun dikatakan tradisional, tidak berarti menutup mata untuk melakukan penyesuaian dengan perkembangan zaman. Sesuai dengan kaidah yang digunakan: al-muhafadhatu alal qadimish shalih walakhdzu bil jadidil ashlah (mempertahankan pola lama yang baik dan mengambil pola baru yang lebih baik). ${ }^{13}$

Depatemen Agama mendefinisikan pendidikan pesentren adalah sebagai lembaga pendidikan Islam yang pada umumnya menggunakan metode nonklasikal. Pada umumnya seorang guru (kiai) mengajar para santri dengan menggunakan kitab-kitab yang berbahasa Arab yang ditulis oleh ulama-ulama terdahulu yang mayoritas para santrinya menetap di dalam pesantren tersebut. ${ }^{14}$

Dalm pesantren, kiai merupakan tokoh sentral yang menjadi rujukan setiap masyarakat pesantren itu sendiri, sehingga duni kiai dan pesantren dalam beberapa waktu terakhir sangat menarik dan selalu aktual untuk dibicarakan apalagi berkaitan dengan perkembangan dunia pendidikan Islam. Studi sosial tentang pemimpin Islam di Indonesia menunjukkan bahwa kiai adalah tokoh utama yang mempunyai posisi dalam masyarakat, baik masyarakat kota, pinggiran dan bahkan pedesaan. Kiai pada posisi ini berfungsi sebagai orang terdidik dalam berbagai bidang. Sehingga elit terdidik, kiai memberikan pengetahuan kepada masyarakat terutama yang berkenaan dengan keislaman dan kepesantrenan sebagai lembaga pendidikan Islam untuk melakukan sebuah proses pengembangan masyarakat. Bahkan awal mula kemunculan tradisi pendidikan pesantren ada yang mengatakan bahwa pendidikan pesantren ini merupakan asli tradisi Indonesia, sehingga pendidikan pondok pesantren ini merupakan ciri yang khas Indonesia. Pendidikan pesantren merupakan lembaga pendidikan tradisional tertua di Indonesia yang kemudian menjadi salah satu benteng pertahanan umat Islam yang berfungsi sebagai pusat dakwah dan pengembangan pusat muslim di Indonesia. ${ }^{15}$

\footnotetext{
10 Ahmad Kamaruzzaman Bustamam, Islam Historis: Dinamika Studi Islam di Indonesia, cet. II, 123124.

11 Ibid. 125-126.

12 Mastuhu, Dinamika Sistem Pendidikan Pesantren: Suatu Kajian tentang Unsur dan Nilai Sistem Pendidikan Pesantren, 55.

13 Choirul Fuad Yusuf dkk, Pesantren dan Demokrasi: Jejak Demokrasi dalam Islam, 248.

14 H. Iskandar Engku dan Siti Zubaidah, Sejarah Pendidikan Islami, (Bandung: PT Remaja Rosdakarya, 2014), 172.

15 Supandi, "Performance Perguruan Tinggi Berbasis Pesantren dalam Meraih Simpatik Masyarakat" Kabilah: Journal of Social Community STAI Nazhatut Thullab Sampang, Vol. 2 No. 2 Desember 2017, 363-367.
} 
Dewasa in, istilah pesantren hanya dapat ditemui di Pulau Jawa. Sementara di daerah lain, istilah pesantren. Misalnya di Aceh dikenal dengan sebutan dayah, dan di Padang dikenal dengan istilah surau. Di Aceh lembaga dayah telah berdiri sejak tahun $225 \mathrm{H} / 840 \mathrm{M}$. Pendirian lembaga tersebut dimulai sejak Islam datang pertama kali ke daerah itu. Menurut Ali Hasjmy, Sultan Kerjaan Peureulak mendirikan lembaga pendidikan Islam yang gurunya mendatangkan dari Arabia, Persia dan Gujarat.adapun surau, pertama kali didirikan oleh Syaikh Burhanuddin di Ulakan dan Pariaman setelah ia kembali dari Aceh yang merupakan tempat ia belajar dengan Syaikh Abdurra'uf Singkil. Taufik Abdullah mencatat bahwa pengaruh Ulakan bagi perkembangan Islam di Minangkabau cukup besar sehingga dalam tradisi sejarah di kalangan para ulama sering muncul anggapan bahwa kota kecil ini adalah sumber penyebaran Islam.

Lebih dari itu, pesantren di Jawa didirikan oleh Raden Fatah pada tahun 1475 M di hutan Glagah Arum di sebelah selatan Jepara. Pesantren itu mendapat kemajuan pesat sehingga Glagah Arum sebagai kampung kecil juga ikut maju, akhirnya berubah menjadi kota kabupaten, yaitu Bintara dan Raden Fatah sebagai bupatinya. Dengan demikian, dugaan Martin van Bruinessen yang mengatakan bahwa lembaga yang layak disebut pesantren belum berdiri sebelum abad ke-18, masing perlu diteliti lagi. ${ }^{16}$

Pondok pesantren pertam kali di Indonesia dan di Jawa tepatnya di desa Gapura, Gresik dirikan oleh Syaikh Maulana Malik Ibrahim pada abad ke-17 M, yang berasal dari Gujarat, India. Pesantren mempunyai fungsi penting sebagai pusat pendidikan dan penyiaran agama Islam. Maulana Malik Ibrahim mendidik sejumlah santri yang ditampung dan tinggal bersama dalam rumahnya di Gresik. Tokoh yang dianggap berhasil mendidik ulama dan mengembangkan pondok pesantren adalah Sunan Ampel yang mendirikan pesantren di Kemabang Kuning Surabaya. Bahkan pada msa permulaan tumbuhnya pondok pesantren hanyalah berfungsi sebagai alat Islamisasi, yang sekaligus berfungsi memadukan tiga unsur pendidikan, yaitu ibadah untuk menanamkan iman, tabligh untuk menyebarkan ilmu dan amal dan untuk mewujudkan kegiatan kemasyarakatan dalam kehidupan sehari-hari. ${ }^{17}$

\section{Unsur-unsur dalam Pesantren}

Dalam sebuah pondok pesantren terdapat beberapa elemen yang satu dengan yang lain ada kaitannya, yakni ada kiai, ada pondok, ada masjid, ada santri dan ada pengajaran kitab kuning (kalsik).

Pertama, kedudukan seorang kiai atau guru biasanya menernagkan pelajarnnya dengan menggunakan kitab kuning yang berbahasa Arab yang dikenal dengan istilah nagji dan kegiatan ini merupakan kegiatan yang dianggap suci oleh para santri yang menyerahkan atau menitipkan hidupnya kepada kiai yang selain sangat dihormati juga biasanya sangat tua dan sudah menunaikan ibadah haji karena kemampuannya. Corak kehidupan kiai terkadang menempati multifungsi, satu sisi berfungsi sebagai imam dalam bidang ubudiyah dan di sisi lain berfungsi

\footnotetext{
16 Ahmad Kamaruzzaman Bustamam, Islam Historis: Dinamika Studi Islam di Indonesia, cet. II, 123124.

17 M. Shodiq, “Pesantren Dan Perubahan Sosial”, Jurnal Sosiologi Islam, Vol. 1 No. 1 April 2011.
} 
sebagai pemimpin dalam urusan kemasyrakatan. ${ }^{18}$ Kiai sebagai komponen pesantren merupakan orang yang mengandung pengertian pensucian dan penghormatan kepada orang-orang terhormat. Mereka memperoleh gelar kiai karena kelebihan-kelebihan yang dimiliki, seperti kelebihan moral dan intelektual yang ditransmisikan di pesantren kepada para santri mereka. Menurut Lukens Bull, kelebihan kiai pesantren terletak pada tiga hal, yaitu; kekuatan supranatural, keluasan ilmu agama Islam, dan standar moralitas yang lebih tinggi. Bahkan diyakini memiliki barokah kerena mereka merupakan pewaris para Nabi. ${ }^{19}$

Unsur pesantren yang kedua adalah masjid yang merupakan tempat atau sarana untuk melaksanakan peribadatan para santri. ${ }^{20}$ Bahkan dalam sejarahnya, pendidikan Islam sangat erat kaitannya dengan masjid. Karena itu, apabila membicarakan masjid berarti sedang membicarakan lembaga yang dipandang sebagai tempat yang sangat asasi untuk menyiarkan ilmu pengetahuan dan kebudayaan Islam. Fungsi masjid, terutama pada periode klasik sangat luas. Selain sebagai sarana ibadah, masjid juga dijadikan sebagai tempat memberi pelajaran (pendidikan), sarana kegiatan memutuskan persoalan baik hukum (pengadilan) dan bahkan sebagai sararna aktivitas pemerintahan. ${ }^{21}$

Unsur yang ketiga dalam pesantren adalah asrama, yang dalam beberapa kalangan menyebutnya dengan istilah pondok. Di mana fungsi dari keberdaan pondok ini sebagai tempat para santri atau peserta pelajar untuk tinggal sementara selama mereka menuntut ilmu di lembaga pesantren ini. Unsur yang keempat dari pesantren adalah keberadaan para santri atau peserta pelajar di lembagai ini. Mengenai kuantitas santri ini dapat dipresentasekan seberapa kuat karisma kiai di mata masyarakat. Artinya semakin kuat karisma kiai akan semakin banyak pula kuantitas santri. Sebaliknya semakin melemah karisma seorang kiai maka akan semakin sedikit pula sisi kuantitas santri yang ada.

Unsur yang kelima dari pesantren adalah adanya pengajaran kitab kuning yang merupakan mutlak dibutuhkan dalam pendidikan pesantren, terutama di pesantren yang masih tergolong salaf.22 Pesantren sesungguhnya merupakan uapaya memelihara dan mentransfer literatur-literatur Islam klasik yang lazim disebut kitab kuning dari genirasi ke genirasi selama berabad-abad. Menurut Abdurrahman Wahid, pengajaran kitab-kitab Islam klasik oleh pesantren dijadikan sebagai sarana untuk membekali para santri dengan pemahaman warisan keilmuan Islam masa lampau atau jalan kebenaran menuju kesadaran esoteris ihwal status penghambaan (ubudiyah) di hadapan Tuhan. Tujuan pengajaran kitabkitab Islam klasik tersebut merupakan salah satu cara yang ditempuh oleh pesantren untuk membekali para calon ulama akan ilmu-ilmu keislaman yang kelak akan ditransfer keapada masyarakat secara lebih luas.

Adapun kitab-kitab Islam klasik yang diajarkan menurut Nurcholis Madjid dapat digolongkan menjadi tujuh kelompok, yaitu nahwu (syntax) dan sharaf

\footnotetext{
18 Supandi. 368.

19 Abdullah Aly, Pendidikan Islam Multikultural di Pesantren: Telaah Terhadap Kurikulum Pondok Pesantren Modern Islam Assalaam Surakarta, (Yogyakarta: Pustaka Pelajar, 2011), 159-160.

20 Supandi. 368.

21 Zakiah Daradjat, Ilmu Pendidikan Islami, (Jakarta: PT Bumi Aksara, 2012), 75.

22 Supandi, "Performance Perguruan Tinggi Berbasis Pesantren dalam Meraih Simpatik Masyarakat", 368.
} 
(morphology); fikih; aqa'id; atau ushuluddin; tasawuf atau etiks; tafsir; hadis; dan bahasa Arab. Metode pembelajara umum dilakukan pada pengajaran kitab-kitab kuning di pesantren adalah sorogan dan weton. Metode sorogan adalah metode pembelajaran kitab secara individual, di mana setiap santri menghadap secara bergiliran kepada kiai untuk membaca, mejelaskan dan menghafal pelajaran yang diberikan sebelumnya. Metode weton adalah metode pembelajaran kitab secara kelompok, di mana kiai membaca, menerjemahkan, dan menjelaskan pengertian isi kitab yang dikaji, sementara para santri menyimak sambil memberikan harakat dan menulis penjelasannya di sela-sela kitabnya. ${ }^{23}$

\section{Tipologi Pendidikan Pesantren}

Berdasarkan keputusan Menteri Agama RI No. 3/1979 yang membagi pondok pesantren menjadi empat tipe. Pertama, pesantren tipe A, yaitu pondok pesantren tempat para santri belajar dan bertempat tinggal bersama dengan guru (kiai), kurikulum terserah pada kiainya, cara memberi pelajaran secara individaul, dan tidak menyelenggarakan madrasah untuk belajar. Kedua, pesantren tipe B, yaitu pondok pesantren yang mempunyai madrasah dan mempunyai kurikulum, pengajaran dari kiai dilakukan dengan cara studium general, pengajaran pokok terletak pada madrasah yang diselenggarakannya, kiai memberikan pelajaran secara umum kepada para santri pada waktu yang telah ditentukan, para santri tinggal di lingkungan itu dan mengikuti pelajaran-pelajaran dari kiai, dan di samping mendapat ilmu agama juga mendapat ilmu pengetahuan umum di madrasah.

Ketiga, pesantren tipe C, yaitu pondok pesantren yang memiliki fungsi utama sebagai tempat tinggal atau asrama, para santri belajar di madrasah dan sekolahsekolah umum, fungsi kiai di sini sebagai pengawas, pembina mental dan pengajar agama. Keempat, pesantren tipe D, yaitu pondok pesantren yang menyelenggarakan sistem pondok dan sekaligus sistem sekolah umum dan madrasah. ${ }^{24}$

Selain pendapat di atas, juga terdapat beberapa pendapat yang membagi pendidikan pondok pesantren menjadi tiga tipe. Pertama, pondok pesantren tradisional. Ciri khas pondok pesantren ini hanya mengajarkan kitab kuning yang tulis oleh ulama abad ke 15 yang berbahasa Arab. Pola pembelajarannya menggunakan sistem halaqah tersebut biasanya dilakukan di masjdi atau suarau. Tujuan dari pembelajaran sistem halaqah ini adalah hafalan. Kedua, pondok pesantren modern. Tipe kedua ini merupakan pengembangan dari tipe pertama di atas di mana sistem pembelajarannya cenderung mengadopsi sistem modern saja. Dengan demikian, proses pembelajarannya tampak pada penggunaan ruang kelaskelas belajar baik dalam bentuk madrasah maupun sekolah. Kurikulum yang digunakan adalah kurikulum madrasah atau sekolah yang berlaku secara tradisional. Kondisi santri ada yang menetap dan ada yang tersebar disekitar desa itu. Ketiga, tipe pondok pesantren komprehensif, yaitu pondok pesantren yang memadukan antara sistem pendidikan dan pengajaran tradisional dan yang modern. Artinya, di samping menerapkan sitem pedidikan yang modern akan

${ }^{23}$ Abdullah Aly, Pendidikan Islam Multikultural di Pesantren: Telaah Terhadap Kurikulum Pondok Pesantren Modern Islam Assalaam Surakarta, 171.

${ }^{24}$ Ahmad Kamaruzzaman Bustamam, Islam Historis: Dinamika Studi Islam di Indonesia, cet. II, 126. 
tetapi juga tetap melestarikan pengajaran kitab-kitab kuning sebagai bahan kajian para santri dengan menggunakan metode bendongan, dan wetnan. ${ }^{25}$

Istilah yang berbeda juga dikemukakan oleh Wardi Bahktiar dkk, yang membagi pesantren dilihat dari pengetahuan yang diajarkannya menjadi dua macam: Pertama, pesantren salafi, yaitu pesantren yang mengajarkan kitab-kitab Islam klasik. Sistem madrasah diterapkan untuk mempermudah teknik pengajaran sebagai pengganti metode sorogan. Jenis pesantren ini tidak diajarkan pengetahuan umum. Kedua, pesantren khalafi, yaitu di samping memberikan pengajaran kitab Islam klasik, juga membuka pendidikan sekolah umum. Penggunaan istilah salafi dan khalafi tersebut di atas, dimaksudkan untuk menghindari pemakaian istilah pesantren tradisional dan modern. ${ }^{26}$

\section{Kurikulum Pendidikan Pesantren}

Penyelenggarakan kegiatan pendidikan dan pengajaran untuk para santri dengan berbagai macam materi disampaikan dengan berbagai macam metode pembelajaran. Dalam pesantren tradisional, keseluruhan kegiatan pembelajaran tidak sebagaimana pada sistem pendidikan formal, seperti jenjan dan lama waktu belajar karena tidak ada keharusan menempuh ujian untuk memperoleh ijazah. Di samping itu, masa belajar para santri tidak sama karena didasarkan pada kemampuan santri serta kurikulum pelajaran yang demikian lentur. Di samping itu, bahan materi yang disampaikan kepada santri bersifat aplikatif, artinya materimateri yang telah dipelajarinya harus diterjemahkan ke dalam perbuatan dan aktivitas keseharian. ${ }^{27}$

Berkaitan dengan kurikulum pesantren selama ini diberi kebebasan oleh negara untuk menyusun dan melaksanakan kurikulum pendidikan secara bebas dan merdeka. Menurut Luknes-Bull secara umum kurikulum pesantren dapat debedakan menjadi empat bentuk, yaitu: Pertama, kurikulum berbentuk pendidikan agama Islam. Dalam dunia pesantren, kegiatan belajar pendidikan agama Islam lazim disebut dengan ngaji atau pengajian. Kegiatan ngaji dipesantren dalam praktiknya dapat dibedakan menjadi dua tingkatan. Tingkatan paling awal ngaji sangatlah sederhana, yaitu para santri belajar bagaimana cara membaca teksteks arab, terutama sekali al-Quran. Tingkatan berikutnya adalah para santri memilih kitab-kitab Islam klasik dan mempelajarinya di bawah bimbingan kiai.

Kedua, kurikulum berbentuk pengalaman dan pendidikan moral. Pesantren menempatkan pengalaman dan pendidikan moral sebagai salah satu kegiatan pendidikan penting. Kegiatan-kegiatan keagamaan yang paling ditekankan adalah kesalehan dan komitmen para santri terhadap lima rukun Islam. Kegiatan tersebut diharapkan dapat menumbuhkan kesadaran para santri untuk mengamalkan nilainilai moral yang diajarkan pada saat ngaji. Nilai-nilai moral yang ditekankannya adalah persaudaraan Islam, keikhlasan, kesederhanaan, dan kemandirian.

Ketiga, kurikulum berbentuk sekolah dan pendidikan umum. Pesantren memberlakukan kurikulum sekolah dengan mengacu kepada pendidikan nasional yang dikeluarkan oleh Departemen Pendidikan Nasional, sedangkan untuk

25 H. Muwahid Shulhan dan H. Soim, Manajeman Pendidikan Islam: Strategi Dasar Menuju Peningkatan Mutu Pendidikan Islam, (Yogyakarta: Teras, 2013), 155-156.

26 Tafsir, Ilmu Pendidikan Islami, 293.

${ }^{27}$ H. Iskandar Engku dan Siti Zubaidah, Sejarah Pendidikan Islami, 178. 
kurikulum madrasah mengacu kepada pendidikan agama yang dikeluarkan oleh Departemen Agama.

Keempat, Kurikulum berbentuk keterampilan dan kursus. Pesantren memberlakukan kurikulum tersebut secara terencana dan terprogram melalui kegiatan ekstrakurikuler. Kurikulum tersebut dilaksanakan karena dua alasan, yaitu: politis dan promosi. Yang dimaksud alasan politis adalah pesantren dalam memberikan pendidikan keterampilan dan kursus kepada para santri dalam rangka merespon seruan pemerintah untuk peningkatan kemampuan sumber daya manusia (SDM). Sedangkan yang dimaksud alasan promosi adalah karena terjadi peningkatan jumlah calon santri yang memilih pesantren-pesantren modern dan terpadu, dengan alasan karena terdapat pendidikan keterampilan dan kursus di dalamnya. ${ }^{28}$

\section{Tujuan Pendidikan Pesantren}

Sejak awal pertumbuhannya, fungsi utama pesantren adalah menyiapkan santri mendalami dan menguasai ilmu agama Islam, atau lebih dikenal tafaqquh fi al-din, yang diharapkan dapat mencetak kader-kader ulama dan turut mencerdaskan masyarakat Indonesia dan melakukan dakwah menyebarkan agama Islam serta benteng pertahanan umat Islam dalam bidang akhlak. Sejalan dengan fungsi tersebut, materi yang diajarkan dalam pondok pesantren semuanya terdiri dari materi agama yang diambil dari kitab-kitab klasik yang berbahasa Arab atau lebih dikenal dengan kitab kuning.

Pesantren sebagai lembaga pendidikan yang memiliki akar kuat (indigenous) pada masyarakat muslim Indonesia, dalam perjalanannya mampu menjaga dan mempertahankan keberlangsungan dirinya serta memiliki model pendidikan multi aspek. Santri tidak hanya dididik menjadi seorang yang mengerti ilmu agama, tetapi juga mendapat tempaan kepemimpinan yang alami, kemandirian, kesederhanaan, ketekunan, kesetaraan, dan sikap positif lainnya. Model inilah yang diharapkan melahirkan masyarakat yang berkualitas dan mandiri sebagai bentuk partisipasi pesantren dalam menyukseskan pembangunan nasional sekaligus berperan aktif dalam mencerdaskan bangsa sesuai yang diamanatkan oleh Undang-undang 1945. ${ }^{29}$

Mastuhu secara spesifik mengemukakan tujuan pendidikan pesantren untuk menjadikan dan mengembangkan kepribadian muslim, yaitu kepribadian yang beriman dan bertakwa kepada Tuhan, berakhlak mulia, bermanfaat bagi masyarakat atau berkhidmat kepada masyarakat dengan jalan menjadi abdi masyarakat tetapi rasul, yaitu menjadi pelayan masyarakat sebagaimana kepribadian Nabi Muhammad (mengikuti Sunnah Nabi), mampu berdiri sendiri, bebas dan teguh dalam kepribdian, menyebarkan agama atau menegakkan Islam dan kejayaan umat Islam di tengah-tengah masyarakat ('izzul Islam wal Muslimin),

\footnotetext{
${ }^{28}$ Abdullah Aly, Pendidikan Islam Multikultural di Pesantren: Telaah Terhadap Kurikulum Pondok Pesantren Modern Islam Assalaam Surakarta, (Yogyakarta: 2011), 183-190.

29 Muhammad Idris Usman, "Pesantren Sebagai Lembaga Pendidik Islam: Sejarah Lahir, Sistem Pendidikan dan Perkembangannya Masa Kini”, Jurnal Al-Hikmah, Vol. XIV No. I 2013.
} 
dan mencintai ilmu dalam rangka mengembangkan kepribadian Indonesia. Idealnya pengembangan kepribadian yang ingin dituju ialah kepribadian muhsin. ${ }^{30}$

Pesantren sebagai lembaga pendidikan Islam, secara umum memliki dua peran, yaitu: (1) sebagai center of excelent yang berfungsi mencetak ulama, dan (2) sebagai agent of development yang berperan dalam pengembangan masyarakat. Tetapi tidak semua pesantren memiliki kedua peran tersebut. ${ }^{31}$ Sebagaimana peran di atas, pesantren merupakan satu-satunya lembaga pendidikan Islam di Indonesia yang mewarisi khazanah intelektual Islam tradisional yang amat kaya. Bahkan mempunayai arti yang sangat signifikan dalam mengembangkan kehidupan di wilayah Indonesia. Dalam hal ini, secara detail terdapat bentuk peranan-peranan pendidikan pesantren, yaitu:

Pertama, peranan instrumental. Upaya pendidikan secara nasioanal tak pelak lagi memerlukan sarana-sarana sebagai media untuk mengejawantahkan tujuantujuannya. Sarana-sarana itu selain dibentuk secara formal juga nonformal murni swadaya dari masyarakat. Dalam tataran ini fungsi pendidikan pesantren sebagai lembaga pendidikan Islam tampak partisipatif. Peran instrumjental pondok pesantren demikian itu dalam kenyataannya memang cukup kuat meskipun perkembangannya sampai dewasa ini masih sangat dibutuhkan lebih serius.

Kedua, peranan keagamaan. Dalam pelaksanaannya pendidikan pesantren melaksanakan proses pembinaan pengetahuan, sikap dan kecakapan yang menyangkut keagamaan. Tujuan utama yaitu terbentukanya insan yang berakhlak dan bermoral tinggi dengan pengamalan pada keagamaan-keagamaan yang konsisten. Dalam hal ini pendidikan agama Islam diintegeralkan melalui sekolah umum maupun madrasah. Pendidikan pesantren juga menyelenggarakan pembinaan terhadap mental dan sikap para santri untuk hidup mandiri meningkatkan keterampilan dan berjiwa interpreneurship karena di dalam pesantren mereka hidup secara bersama dan masing-masing memiliki kewajiban dan hak yang saling mereka jaga dan hormati. ${ }^{32}$

\section{Nilai-nilai Religius Pendidikan Pesantren}

Nilai adalah suatu konsep yang berada dalam pikiran manusia yang sifatnya tersembunyi, tidak berada dalam dunia yang empiris. Nilai berhubungan dengan pandangan seseorang tentang baik dan buruk, indah dan tidak indah, layak dan tidak layak, adil dan tidak adil dan lain sebagainya. Pandangan seseorang tentang semua itu tidak bisa diraba, kita hanya mungkin dapat mengetahuinya dari perilaku yang bersangkutan. Oleh karena itu, nilai pada dasarnya standar perilaku, ukuran yang menentukan atau kriteria seseorang tentang baik dan buruk sehingga standar itu akan mewarnai perilaku seseorang. ${ }^{33}$ Selain itu, nilai adalah ukuran umum yang dipandang baik oleh masyarakat dan menjadi pedoman dari tingkah laku manusia tentang cara hidup yang sebaik-baiknya. ${ }^{34}$

30 Muljono Damopoli, Pesantren Modern IMMIM Mencetak Muslim Modern, (Jakarta: Rajawali Pers, 2011), 82.

${ }^{31}$ Choirul Fuad Yusuf dkk, Pesantren dan Demokrasi: Jejak Demokrasi dalam Islam, 112.

32 H. Iskandar Engku dan Siti Zubaidah, Sejarah Pendidikan Islami, 176.

33 H. Wina Sanjaya, Strategi Pembelajaran Berorientasi Standar Proses Pendidikan, (Jakarta: Kencana, 2011), 274.

34 H. Oemar Hamalik, Dasar-Dasar Pengembangan Kurikulum Cet. Ke-3, (Bandung: PT Remaja Rosdakarya, 2009), 75. 
Yang dimaksud perubahan nilai dalam pembahasan ini adalah kemampuan pengendalian pendidikan pesantren dalam menhadapi arus perubahan niali. Pesantren yang befungsi sebagai basis dakwah sekaligus media kontrol terhadap peirlaku budaya dan pengawal umat menuju maslahat. Sebagai pengawal umat, para kiai dan santri terkadang harus bekerja keras siang dan malam demi mewujudkan kemaslahatan di tengah kehidupan umat. Bahkan sesekali mereka harus bertarung (ideologi) dengan masyarakat setempat yang enggan menerima nilai-nilai baru yang mereka bawa.

Bahkan ada sebutan nilai putih, yakni sebuah sistem nilai moral keagmaan yang bersumber dari Al-Quran, As-Sunnah dan kitab-kitab kuning. Sementara sistem nilai yang dianut masyarakat sebelum kedatangan pesantren adalah nilai hitam, yakni sebuat sistem nilai yang bersumber dari hawa nafsu, misalnya mo limo (lima kebiasaan buruk), antara lain: maling (mencuri), madon (melacur), minum (minum-minuman keras), madat (candu), dan main (judi), serta nilai-nilai lainnya yang tidak terpuji dan bertentangan dengan ajaran Islam. ${ }^{35} \mathrm{Hal} \mathrm{ini,} \mathrm{sejalan}$ dengan pendapat Horikoshi bahwa kewajiban kiai bersumber dari beberapa hal, yaitu; kredibilitas moral, kemampuan mempertahankan pranata sosial dan kemampuan supra rasional yang dimilikinya. Kredibiltas moral dibina dengan dukungan keilmuan (pengetahuan agama, kemampuan membaca kitab kuning), kesalihan perilaku (termasuk ketaan melakukan ibadah ritual), pelayanan kepada masyarakat muslim. ${ }^{36}$

Di samping itu, nilai-nilai yang berlaku dikalangan pendidikan pesantren para santri memiliki budaya tawadu' dan mohon restu dari sang kiai. Meskipun para santri memiliki pilihan untuk mengekspresikan nilai-nilai reformatif dan transformatif, mereka tidak bisa melepaskan diri dari identitas budaya santri yang ikhlas, tawadu', zuhud, dan wara'. Dengan nilai tersebut, para santri meletakkan kiai pada posisi yang harus dihormati. Karena mereka meyakini sepenuhnya bahwa seorang kiai memiliki kecendikiaan yang tinggi, intelektualitas yang memadai, dan nilai-nilai keilmuan yang tinggi. Menurut Hiroko Horikoshi, kiai dipercaya memiliki keunggulan baik secara moral maupun sebagai orang alim, sehingga pengaruhnya sangat diperhitungkan baik oleh para pejabat nasional maupun oleh masyarakat umum. Karena keunggulan-keunggulan yang dimiliki para kiai inilah, para santri tetap menaruh hormat kepada kiai. ${ }^{37}$

Menurut Mastuhu terdapat beberapa niali-nilai religius yang menjadi ciri utama dalam tujuan pendidikan pesantren, yaitu: 1) memilik kebijaksanaan menurut ajaran Islam; 2) mempunyai kebebasan yang terpimpin, yang merupakan watak ajaran Islam; 3) dibiasakan mempunyai rasa solidaritas yang tinggi; 4) mengagungkan kiai (guru) dan kedua orang tua; 5) cinta kepada ilmu pengetahuan. Menurut Al-Quran ilmu pengetahuan datang dari Allah. Banyak sekali hadis yang mengajarkan penting menuntut ilmu dan menjaganya; 6) mandiri, yakni berdiri atas kekuatan sendiri; dan 7) kesederhanaan sikap hidup, yaitu memandang sesuatu terutama materi, secara wajar, proporsional, dan fungsional.

35 Mastuhu, Dinamika Sistem Pendidikan Pesantren: Suatu Kajian tentang Unsur dan Nilai Sistem Pendidikan Pesantren, 21.

36 Ahmad Tafsir, Ilmu Pendidikan Islami, 294.

${ }^{37}$ Choirul Fuad Yusuf dkk, Pesantren dan Demokrasi: Jejak Demokrasi dalam Islam, 169-170. 
Keunggulan utama pada pendidikan pesantren adalah penanaman nilai-nilai keimanan. Bahkan cukup rumit metode penanaman nilai keimanan tersebut. Selain itu, pengaruh kiai, baik dalam hal hubungannya dengan sang khaliq ataupun karena perilakunya sehari-hari, penghormatan orang pada sang kiai, tata letak rumah ibadat, rayuan bacaan shalawat dan pujian menjelang subuh, berbaga upacara keagamaan, semuanya mempengaruhi secara mendalam hati orang, dan bersamaan dengan itu, iman masuk. ${ }^{38}$ Lebih lanjut sebagaimana dikemukakan Kompri, bahwa pesantren juga mengembangkan budaya keteladanan dan kedisiplinan yang meliputi; 1) ketekunan dalam beribadah; 2) kerapian; 3) kedisiplinan; 4) kesopanan; 5) kepedulian; 6) kasih sayang; 7) kebersihan. ${ }^{39}$

Menurut Mukti Ali, ciri-ciri sistem nilai yang dikembangkan pada pendidikan pesantren adalah: 1) antara kiai dan santri terdapat hubungan yang akrab; 2) tunduknya santri kepada kiai. Menurut anggapan para santri menentang kiai selai kurang sopan juga bertentangan dengan ajaran agama; 3) hidup hemat dan sederhana, bahkan terlalu hemat dan sederhana sehingga menyiksa kesehatan badan; 4) Semangat menolong diri sendiri. 5) tolong-menolong dan semangat persaudaraan. Hal ini disebabkan para santri harus mengerjakan pekerjaan yang sama; 6) pendidikan disiplin sangat ditekankan; 7) berani menderita untuk mencapai tujuan; dan 8) kehidupan agama yang baik. ${ }^{40}$

\section{Kesimpulan}

Pendidikan pesantren sebagai lembaga pendidikan Islam yang sudah lama keberadaannya, telah banyak memberikan kontribusi positif bagi pembangunan bangsa ini. Bahkan pra-kemerdekaan pun sudah tampak kontribusi pondok pesantren dalam membantu mengusir para penjajah dari bumi Nusantara. Bahkan tidak sedikit para ulama yang dihasilkan oleh pondok pesantren yang juga berperan aktif dalam membebaskan negara Indonesia dulu dari tangan para penjajah hingga sekarang. Di samping itu, peran pendidikan pesantren dari dulu terlihat dalam membangun bangsa melalui pembinaan moral dan menanamkan nilai-nilai spiritual. Hal tersebut tampak dari perilaku para alumni pondok pesantren yang mayoritas menjadi pemimpin, terutama pemimpin agama dan spiritual.

Dalam sejarahnya, pesantren mempunyai peran yang sangat signifikan pada perkembangan peradaban Indonesia, khususnya Jawa. Pesantren pernah berperan sebagai cultural broker, yaitu penyeleksi budaya yang akan dikonsumsi oleh masyarakat bagi arus modernitas pedesaan. Peran sebagai lembaga keagamaan sekaligus lembaga sosial, pendidikan pesantren mengajarkan, mengembangkan, dan menyebarkan ilmu agama Islam sekaligus nilai-nilai kehidupan yang seimbang. Di samping itu, pendidikan pesantren menjadi aset masyarakat yang didukung dan dipelihara oleh kalangan yang lebih luas serta memiliki kesempatan untuk mewujudkan praktik ibadah sosial dengan memindahkan arena peribadatan dari masjid ke tengah-tengah masyarakat. Bahkan dalam praktik pemberdayaan

\footnotetext{
${ }^{38}$ Ahmad Tafsir, Ilmu Pendidikan Islami, 303-305.

39 Kompri, Manajemen Pendidikan: Komponen-Komponen Elementer Kemajuan Sekolah, (Yogyakarta: Ar-Ruzz Media, 2015), 214.

${ }^{40} \mathrm{Hj}$. Nur Uhbiyati, Ilmu Pendidikan Islam (IPI) Untuk Fakultas Tarbiyah Komponen MKDK, (Jakarta: Departemen Agama RI, 1995), 270.
} 
tersebut dilakukan dengan cara mendekatkan pesantren dengan masyarakat sehingga proses penanaman nilai dapat terealisasi secara bai serta mudah diserap oleh masyarakat setempat.

Banyak nilai-nilai yang diterapkan di dalam pendidikan pesantren tidak hanya membimbing para santri untuk menguasai berbagai ilmu pengetahuan baik agama maupun ilmu umum, akan tetapi mereka juga ditutut agar membiasakan budaya tawadu', ikhlas, zuhud, dan wara' dalam kehidupan sehari-hari sehingga hal tersebut menjadi krakter yang tertanam dalam jiwa mereka. Di samping itu, mereka juga ditutut agar saling menghormati terhadap sesama santri, guru, dan bahkan kiai sehingga menjadi kepribadian serta dapat mengaplikasikannya dalam kehidupan sehari-hari dalam kehidupan nyata.

\section{Daftar Pustaka}

Aly, Abdullah, Pendidikan Islam Multikultural di Pesantren: Telaah Terhadap Kurikulum Pondok Pesantren Modern Islam Assalaam Surakarta, (Yogyakarta: 2011)

Damopoli, Muljono, Pesantren Modern IMMIM Mencetak Muslim Modern, (Jakarta: Rajawali Pers, 2011)

Daradjat, Zakiah, Ilmu Pendidikan Islam, (Jakarta: PT Bumi Aksara, 2012)

H. Iskandar Engku dan Siti Zubaidah, Sejarah Pendidikan Islami, (Bandung: PT Remaja Rosdakarya, 2014)

H. Muwahid Shulhan dan H. Soim, Manajeman Pendidikan Islam: Strategi Dasar Menuju Peningkatan Mutu Pendidikan Islam, (Yogyakarta: Teras, 2013)

Kamaruzzaman Bustamam, Ahmad, Islam Historis: Dinamika Studi Islam di Indonesia, cet. II, (Yogyakarta: Jogja Bangkit Publisher, 2017)

Kompri, Manajemen Pendidikan: Komponen-Komponen Elementer Kemajuan Sekolah, (Yogyakarta: Ar-Ruzz Media, 2015)

Khalil, Muhammad, Sejarah Kebudayaan Islam, (Jakarta: Kementerian Agama Republik Indonesia, 2016)

Sanjaya, H. Wina, Strategi Pembelajaran Berorientasi Standar Proses Pendidikan, (Jakarta: Kencana, 2011)

Supandi, "Performance Perguruan Tinggi Berbasis Pesantren dalam Meraih Simpatik Masyarakat" Kabilah: Journal of Social Community STAI Nazhatut Thullab Sampang, Vol. 2 No. 2 Desember 2017

Tafsir, Ahmad, Ilmu Pendidikan Islami, (Bandung: PT. Remaja Rosdakarya, 2013)

Undang-undang Republik Indonesia No. 20 Tahun 2003 tentang Sistem Pendidikan Nasional (SISDIKNAS)

Uhbiyati, Hj. Nur, Ilmu Pendidikan Islam (IPI) Untuk Fakultas Tarbiyah Komponen MKDK, (Jakarta: Departemen Agama RI, 1995)

Yusuf, Choirul Fuad, Pesantren dan Demokrasi: Jejak Demokrasi dalam Islam, (Jakarta: CV. Titian Pena Abadi, 2011) 